\title{
The ferns of the late Ladinian, Middle Triassic flora from Monte Agnello, Dolomites, N-Italy
}

Evelyn Kustatscher, Elio Dellantonio, and Johanna H.A. Van Konijnenburg-Van Cittert Acta Palaeontologica Polonica 59 (3), 2014: 741-755 doi: http://dx.doi.org/10.4202/app.2012.0076

Several fern remains are described from the para-autochthonous early late Ladinian flora of the Monte Agnello (Dolomites, N-Italy). The plants are preserved in subaerially deposited pyroclastic layers. Some ferns, known already from the Anisian and Ladinian of this area, are confirmed (Neuropteridium elegans), but several taxa are described for the first time (Phlebopteris fiemmensis sp. nov., Cladophlebis ladinica sp. nov., Chiropteris monteagnellii sp. nov.). Cladophlebis sp. and some indeterminable fern remains cannot yet be assigned to any family. Phlebopteris fiemmensis is now the oldest formally established species in the genus. The fern family Dipteridaceae (Thaumatopteris sp. and some fragments probably belonging to the Dipteridaceae because of their venation) has not been recorded previously from European sediments as old as the Ladinian. Although stratigraphically attributed to the late Ladinian, the flora is markedly distinct from other Ladinian floras of the Dolomites and the Germanic Basin. The flora from Monte Agnello shows a higher diversity in ferns than coeval floras from this area although characteristic elements of the Ladinian of the Dolomites such as Anomopteris and Gordonopteris are missing. The new flora misses also the Marattiales (e.g., Danaeopsis, Asterotheca) and other elements such as Sphenopteris schoenleiniana, typical for the Ladinian of the Germanic Basin.

Key words: Dipteridaceae, Matoniaceae, Phlebopteris, Cladophlebis, Chiropteris, Thaumatopteris, plant fossils, Middle Triassic, Southern Alps, Italy.

Evelyn Kustatscher [evelyn.kustatscher@naturmuseum.it], Naturmuseum Südtirol, Bindergasse 1, 39100 Bolzano, Italy; Elio Dellantonio [elio.dellantonio@mtsn.it ], Museo Geologico delle Dolomiti, Piazza SS. Filippo e Giacomo 1, 38037 Predazzo (TN); Johanna H.A. van Konijnenburg van Cittert [Han.Konijnenburg@naturalis.nl , j.h.a.vankonijnenburg@uu.nl], Naturalis Biodiversity Center, PO Box 9517, 2300 RA Leiden and The Netherlands and Laboratory of Palaeobotany and Palynology, Budapestlaan 4, 3584 CD Utrecht, The Netherlands. 
This is an open-access article distributed under the terms of the Creative Commons

Attribution License (for details please see creativecommons.org), which permits unrestricted use, distribution, and reproduction in any medium, provided the original author and source are credited.

Forif Full text $(1,568.6 \mathrm{kB})$ 